\title{
An endophytic Bacillus strain promotes growth of oil palm seedling by fine root biofilm formation
}

\author{
Md Hoirul Azri ${ }^{\mathrm{a}, \mathrm{b}}$, Salmah Ismail ${ }^{\mathrm{a}, *}$, Rosazlin Abdullah $^{\mathrm{a}}$ \\ a Institute of Biological Sciences, Faculty of Science, University of Malaya, 50603 Kuala Lumpur, Malaysia \\ ${ }^{\mathrm{b}}$ Department of Plant Science, Kulliyyah of Science, International Islamic University of Malaysia, 25200 Kuantan, Pahang, Malaysia
}

\section{A R T I C L E I N F O}

\section{Keywords:}

Bacillus sp

Endophyte

Elaeis guineensis Jacq.

Rhizobacteria

\begin{abstract}
A B S T R A C T
Plant-microbe interaction is one of the most important determining factors that could influence plant health and soil fertility. In this research, plant-microbe interaction between Bacillus salmalaya strain 139SI and oil palm (Elaeis guineensis Jacq.) was initiated by inoculating B. salmalaya strain 139SI at the early stage of oil palm seedling growth. Colonization of the strain 139SI on oil palm seedling roots and its mechanisms of plant growth promotion were evaluated and characterized. Analysis of strain 139SI colonization showed that the strain colonizes and attached to the root surface by forming biofilm. The strain 139SI was identified as endophytic bacteria as it shows the ability to colonize plant rhizosphere and penetrate into the plant internal root tissue. The results also indicate that the strain was positive for indole acetic acid (IAA), nitrogen fixation, phosphate solubilization, and siderophores production. The plant growth promoting features of strain 139SI were further confirmed by growth enhancement of oil palm seedling inoculated with this strain. The overall findings of this study suggest that associations of this novel strain could enhance growth quality of oil palm seedlings, hence, enable better adaptation of the seedlings to the environmental conditions of the planting site.
\end{abstract}

\section{Introduction}

Agriculture area cultivated with oil palm (Elaeis guineensis Jacq.) in Malaysia has expanded tremendously in recent years. First introduced as an ornamental tree in early 1870 s, oil palm has since undergone significant leaps in production and planted areas to become the most important industrial crop. Palm oil production has risen by more than 2 million tonnes in the past 10 years from 15.8 million tonnes in 2007 to 17.3 million tonnes in 2016. The total area planted with oil palm had increased from 4.3 million hectares in 2007 to 5.7 million hectares in 2016 , an increase of $32.6 \%$ (MPOB, 2017). Various factors have contributed to spurring oil palm industry occupying its present position, including the introduction of high-quality planting material through genetic improvements and also the implementation of good agronomic practices (Wahid et al., 2005).

Breeding and selection of high-quality planting material for oil palm plantation industry are not only focusing on achieving high fresh fruit bunch yield, but the quality of the oil produced and desirable vegetative characters such as reduced rates of trunk extension and long bunch stalks are also taken into account (Basri et al., 2003 0in press). Strong demands for high-quality planting material has initiated the efforts to propagate the oil palm through tissue culture. Vegetative propagation of oil palm by tissue culture allows rapid multiplication of uniform planting materials with desired characteristics (Sogeke, 1998).

Besides that, inoculation of plant growth-promoting rhizobacteria (PGPR) at the early stage of oil palm seedling growth is one of the promising alternative strategies as a measure to produce high-quality planting material. Inoculation of PGPR to oil palm seedling at the early stage of growth would enable early associative interactions between the bacteria and the seedling. These early associations would enhance adaptation of the seedlings to the environmental conditions, hence, increase the survival rate (Sturz and Nowak 2000; Azlin et al. 2007). Previous studies have shown that inoculation of PGPR at the early stage of plant growth could significantly enhance survival rates of the host plants (Pandey et al. 2000). Thus, in this study, the potential of a new strain of soil bacteria, B. salmalaya strain 139SI, as plant growth promoting bacteria were evaluated. Subsequently, the effects of strain 139SI inoculation at the early stage of oil palm seedling growth and the colonization of the strain on palm root were also determined.

\footnotetext{
* Corresponding author.

E-mail address: salmah_r@um.edu.my (S. Ismail).
} 


\section{Materials and methods}

\subsection{Screening and isolation of strain $139 S I$}

B. salmalaya strain 139SI (Gen Bank accession No: JF825470.1; ATCC BAA-2268) used in this study was originally isolated from soil obtained from agricultural sites in Selangor, Malaysia $\left(2.99917^{\circ} \mathrm{N}\right.$ $101.70778^{\circ} \mathrm{E}$ ) (Ismail and Dadrasnia, 2015). The soil obtained from the agricultural site was suspended in $3 \mathrm{ml}$ of sterile distilled water and the suspension was later streaked on brain-heart infusion (BHI) agar plates that were supplemented with $5 \%$ sheep blood. Hemolytic colonies emerge on the plate were isolated and purified. The phylogenetic position of strain 139SI was determined based on 16S rRNA gene sequences. The stock culture of strain 139SI was prepared by sub-culturing the bacteria in universal bottles containing $\mathrm{BBL}^{\mathrm{TM}}$ Brain Heart Infusion (BHI) slants and maintained at $4{ }^{\circ} \mathrm{C}$ until required.

\subsection{Quantification of indole acetic acid (IAA)}

IAA content produced by the strain 139 SI was measured spectrophotometrically using the method described by Gordon and Weber (1951). The strain 139SI was cultured in two sets of flasks, one containing $20 \mathrm{~mL}$ of Brain Heart Infusion (BHI) medium supplemented with $0.1 \%(\mathrm{w} / \mathrm{v}) \mathrm{L}$-Tryptophan and the other without L-Tryptophan. The culture was then incubated on orbital shaker $(150 \mathrm{rpm})$ at $30{ }^{\circ} \mathrm{C}$ for $96 \mathrm{~h}$. After $96 \mathrm{~h}$ of incubation, the cultures was centrifuged at $8000 \times \mathrm{g}$ for $20 \mathrm{~min}$ and $1 \mathrm{~mL}$ cell suspension was transferred into a tube and mixed vigorously with $2 \mathrm{~mL}$ of Salkowski's reagent. The mixtures were then incubated at room temperature for $25 \mathrm{~min}$ and the formation of a pink color was measured using a spectrophotometer at $535 \mathrm{~nm}$. The quantity of IAA in the culture filtrate was determined from a standard curve prepared with known concentrations of IAA.

\subsection{Evaluation of phosphate solubilizing activity}

The phosphate solubilizing ability of strain 139SI was evaluated with the National Botanical Research Institute's Phosphate (NBRIP) plate culture [composition $1^{-1}$ : glucose $10 \mathrm{~g}, \mathrm{Ca}_{3}\left(\mathrm{PO}_{4}\right) 5 \mathrm{~g}$, $\mathrm{MgSO}_{4} .7 \mathrm{H}_{2} \mathrm{O} 1 \mathrm{~g}, \mathrm{KCl} 0.2 \mathrm{~g}, \mathrm{NaCl} 1 \mathrm{~g}, \mathrm{NH}_{4} \mathrm{Cl} 5 \mathrm{~g}$ and $2 \%$ general purpose agar-agar, pH 7.0 (Nautiyal, 1999)]. Freshly grown of strain 139SI cultures was inoculated on NBRIP medium and incubated at $30^{\circ} \mathrm{C}$ for $96 \mathrm{~h}$. The phosphate solubilizing ability of strain 139SI was shown by the formation of clear zone around the bacterial colony. The ratio of the diameter of the clear zone to the diameter of the bacterial colony was calculated as a phosphate solubilization index (SI) of the strain 139SI.

\subsection{Siderophores production}

Production of siderophores by strain 139SI was determined qualitatively following the method of Schwyn and Neilands (1987) by using the universal CAS agar plate assay. Composition of CAS-reagent was: $1 \mathrm{mM}$ CAS, $10 \mathrm{ml} \mathrm{FeCl}{ }_{3} \cdot 6 \mathrm{H}_{2} \mathrm{O}$ (1 mM stock) made in $10 \mathrm{mM} \mathrm{HCl}$ and $2 \mathrm{mM}$ N,N-cetyl trimethyl ammonium bromide (CTAB). The CAS-reagent solution was autoclaved separately and added to $500 \mathrm{ml}$ of NA medium. Freshly grown of strain 139SI cultures was spot inoculated on Chrome-Azurol-S (CAS) agar medium and incubated for four days at $30{ }^{\circ} \mathrm{C}$. The color changes of CAS reagent from blue to of yellowish or orange zone around bacterial colony was considered positive for siderophores production.

\section{5. $\mathrm{N}_{2}$ fixation}

The ability of strain 139SI to fix atmospheric $\mathrm{N}_{2}$ was determined qualitatively with $\mathrm{N}$-free semisolid medium (Baldani et al., 2014). Nfree semisolid medium (NFb) contained $\mathrm{L}^{-1}: 5 \mathrm{~g}$ malic acid, $0.5 \mathrm{~g}$ $\mathrm{K}_{2} \mathrm{HPO}_{4}, \quad 0.2 \mathrm{~g} \quad \mathrm{MgSO} \cdot 7 \mathrm{H}_{2} \mathrm{O}, \quad 0.1 \mathrm{~g} \quad \mathrm{NaCl}, \quad 0.02 \mathrm{~g} \quad \mathrm{CaCl} \cdot 2 \mathrm{H}_{2} \mathrm{O}, 1 \mathrm{~g}$
$\mathrm{Na}_{2} \mathrm{MoO}_{4} \cdot 2 \mathrm{H}_{2} \mathrm{O}, 1.175 \mathrm{~g} \mathrm{MnSO} \cdot \mathrm{H}_{2} \mathrm{O}$ ), $4.0 \mathrm{~g} \mathrm{KOH}, 1.4 \%$ agar, $2 \mathrm{~mL}$ bromothymol blue ( $5 \% \mathrm{sol} \mathrm{KOH})$, and the $\mathrm{pH}$ was adjusted at $\mathrm{pH} 7$. The strain 139SI was grown in BHI liquid medium for $48 \mathrm{~h}$ at $30{ }^{\circ} \mathrm{C}$ and $140 \mathrm{rpm}$. Then, $10 \mathrm{~mL}$ of strain 139SI culture was centrifuged for $5 \mathrm{~min}$ at $8,000 \times g$ and the cell pellets were collected and re-suspended in physiological solution $(0.8 \% \mathrm{NaCl})$. After that, an aliquot of $10 \mu \mathrm{L}$ was transferred into vials containing semi-solid $\mathrm{N}$-free media. The ability of strain 139SI to fix atmospheric $\mathrm{N}_{2}$ is evidenced by the formation of a veil-like pellicle near the surface of the semi-solid $\mathrm{N}$-free media.

\section{Promotion of plant growth and bacterial colonizing ability}

\subsection{Bacterial inoculum preparation}

Bacterial inoculum was produced by transferring two loops of strain 139SI from 2 day-old cultures on to BHI plate followed by incubation at $30{ }^{\circ} \mathrm{C}$ for 48 hours. Bacterial cells were scraped from the plate and suspended in PBS buffer $\left(10 \mathrm{mM} \mathrm{NaH}_{2} \mathrm{PO}_{4}\right.$ containing $0.8 \% \mathrm{NaC} 1, \mathrm{pH}$ 6.5). The inoculum concentration was adjusted to approximately $1 \times$ $10^{9} \mathrm{CFU} \mathrm{ml} \mathrm{m}^{-1}$ with PBS, based on the optical density at $600 \mathrm{~nm}$, and was confirmed by plate counting.

\subsection{Seedling preparation and experimental design}

Seeds of oil palm (Elaeis guineensis Jacq.) that have undergone heat treatment to stimulate germination were surface-disinfected by briefly washing in $70 \%$ ethanol, followed by $5 \%$ sodium hypochlorite before it was rinsed several times with sterile distilled water. The distilled water from the last rinse was cultured on BHI medium plates to make sure the seeds were fully sterilized. The sterilized seeds, then immersed in sterile distilled water to raise the moisture content required for germination. Subsequently, the seeds were kept in a polythene bag and stored in the germination room at a temperature $30{ }^{\circ} \mathrm{C}$ for 60 days (Green et al., 2013).

After 60 days, the germinated seeds were collected and placed in a polythene bag. The seeds were sprayed with a mist sprayer of sterile distilled water to raise the moisture content and kept in the germinator room at a temperature $30^{\circ} \mathrm{C}$ for a week. Seedlings characterized with $1.0-1.5 \mathrm{~cm}$ of epicotyl and $2.0-2.5 \mathrm{~cm}$ of root were selected for this experiment. The oil palm seedlings were washed with sterile distilled water several times and the residue from the last rinse was streaked on BHI plates to ensure the seedling free of any microbe before transferred into glass bottle $(15 \mathrm{~cm} \times 5 \mathrm{~cm})$ filled with a $100 \mathrm{~g}$ mixture of sterilized peat and vermiculite $(1: 10, \mathrm{v}-\mathrm{v})$ as a medium to grow the seeds. The growing media were analyzed for $\mathrm{pH}$ and macro and micronutrient contents. The $\mathrm{pH}$ of the dried soil was measured using a $\mathrm{pH}$ meter (soil to water ratio of 1:4) (Thomas, 1996). The amount of nitrogen was determined by Kjedahl method (Bremner and Mulvaney, 1982). While the quantities of other nutrients in soil were determined using an Inductively Coupled Plasma Atomic Emission Spectrometry (ICP-AES) (Jones, 2001). The pH of soil was $=6.78 \pm 0.16$. Percentage of elements in $100 \mathrm{~g}$ soil sample were nitrogen: $0.11 \% \pm 0.06$, phosphorus: $0.10 \% \pm 0.02$, potassium: $0.06 \% \pm 0.01$, magnesium: $0.04 \% \pm 0.02$, calcium: $0.08 \% \pm 0.01$, sulfur: $0.09 \% \pm 0.01$ ). The growth media previously was sterilized by autoclaving three times for $20 \mathrm{~min}$ at $121{ }^{\circ} \mathrm{C}$ with $24 \mathrm{~h}$ intervals. The seedlings were allowed to grow for a week to make sure they were stable before treatment.

The seedlings were then inoculated with $5 \mathrm{ml}$ of $1 \times 10^{9} \mathrm{CFU} \mathrm{ml}{ }^{-1}$ strains 139SI in PBS. The inoculum was mixed into the soil using a sterile metal spatula. Bacterial suspension was replaced with sterile PBS buffer in the control group. Each treatment was comprised 60 replications. Plant vegetative growth and bacterial colonization on a plant's root was assessed by sampling the plants on day 7th, 14th, and 21st after inoculation. 10 replicates were used for analyzing 139SI colonizing ability and the other 10 replicates were used for vegetative growth measurement. The glass bottle that contained the seedling was 
placed in a nursery under natural light and temperature condition [mean temperature: $31 / 25^{\circ} \mathrm{C}$ (day/ night)].

\subsection{Vegetative growth measurement}

Plants were removed from growth medium and roots were gently shaken to remove root-adhering soil. Shoots length, stem diameter, root length and lateral root number were determined as growth parameters. Shoot and root were separated and oven-dried at $70{ }^{\circ} \mathrm{C}$ until constant weight was achieved to determine the dry weight.

\subsection{Bacterial population in rhizosphere}

Roots and rhizosphere vermiculite covered the root from each bottle were weighed and $1 \mathrm{~g}$ of samples were placed in a tube containing $10 \mathrm{ml}$ of sterile PBS water. Then, the samples were shaken vigorously using vortex mixture for two minutes. Resulting suspensions were serially diluted and $100 \mu \mathrm{l}$ aliquots were streaked on BHI plates. The Bacterial growth was recorded after two days incubation at $30^{\circ} \mathrm{C}$ in the dark.

\subsection{Endophytic colonization}

To determine endophytic populations of strain 139SI, $1 \mathrm{~g}$ of root segments from inoculated and non-inoculated plants were surface sterilized with $70 \%$ ethanol for $30 \mathrm{sec}$ followed by $1 \%$ commercial bleach for $30 \mathrm{sec}$ and then washed three times in distilled water (this step was repeated for several times). Root samples were then aseptically macerated in $10 \mathrm{ml}$ PBS with a mortar and pestle. Homogenates were serially diluted and plated on BHI to determine the microbial populations inside surface-sterilized roots. The bacterial colonies were counted after 4 days of incubation at $30^{\circ} \mathrm{C}$ (Chanway et al., 2000).

\subsection{Evaluation of the efficacy of surface sterilization methods}

To determine the efficiency of sterilization, $100 \mu \mathrm{l}$ of distilled water from the last rinse was streaked on BHI medium plates. The surfacesterilized root samples were randomly selected and then submerged in BHI broth media (Baldani et al., 2014). The surface sterilization of root samples was achieved when there was no growth on the media after incubated at $30^{\circ} \mathrm{C}$ for 3 days. Only data from the fully surface-sterilized root samples were selected to be analyzed.

\subsection{Observation of the bacterial colonization on root surface}

Root samples from inoculated and non-inoculated plants were fixed in $2 \%$ glutaraldehyde in $0.1 \mathrm{M}$ sodium cacodylate, $\mathrm{pH} 7.4$, for 2 hours, and post fixed in $1 \%(\mathrm{w} / \mathrm{v})$ osmium tetroxide in the same buffer for 2 hours. Samples then were washed and dehydrated in ethanol and then were followed by critical point drying with liquid carbon dioxide using the CPD 030 (BAL-TEC, Germany). The samples were then mounted on stubs for SEM, spattered with gold (Sputter Coater SCD, 005, BAL-TEC, Germany) and examined with a scanning electron microscope.

\subsection{Statistical analysis}

Results were expressed as means + standard deviation. The vegetative growth results obtained were analyzed by t-test. Data for strain 139SI population density were analyzed using one-way ANOVA with posthoc Tukey's test with the level of significance established at $\mathrm{p}<0.05$. Correlations between strain 139SI population density in rhizosphere and growth parameters were also analyzed.
Table 1

Evaluation of IAA, phosphate-solubilizing, siderophores production and $\mathrm{N}_{2}$ fixation by strain 139SI.

\begin{tabular}{|c|c|c|c|c|}
\hline $\begin{array}{l}\text { IAA production } \\
\text { with } \\
\text { tryptophan ( } \mu \mathrm{g} \\
\mathrm{ml}^{-1} \text { ) }\end{array}$ & $\begin{array}{l}\text { IAA } \\
\text { production } \\
\text { without } \\
\text { tryptophan } \\
\left(\mu \mathrm{gl}^{-1}\right)\end{array}$ & $\begin{array}{l}\text { Phosphate } \\
\text { Solubilizing } \\
\text { zone ratio } \\
(\mathrm{cm})\end{array}$ & $\begin{array}{l}\text { Siderophores } \\
\text { production }\end{array}$ & $\mathrm{N}_{2}$ fixation \\
\hline $36.5 \pm 1.2$ & $18.5 \pm 0.4$ & $1.6 \pm 0.03$ & + ve & + ve \\
\hline
\end{tabular}

The experiments were performed in triplicate and individual values are depicted as mean \pm standard error.

\section{Results}

\subsection{Quantification of IAA, phosphate-solubilizing, siderophoress} production and $\mathrm{N}_{2}$ fixation

Screening results of plant growth promoting traits of strain 139SI are depicted in Table 1. IAA is a growth hormone that PGPR most commonly produce. The strain 139SI was found to be able to produce about $28.5 \pm 0.4 \mu \mathrm{g} \mathrm{ml}^{-1}$ of IAA and higher concentration of IAA were produced in the presence of L-tryptophan $\left(46.5 \pm 1.2 \mu \mathrm{g} \mathrm{ml}^{-1}\right)$. Phosphate solubilizing bacteria convert insoluble phosphate in the soil into soluble form by producing organic acids. The 139SI strain was observed able to grow well on NBRIP agar medium and developed halo zone, a clear indication that this strain is active in phosphate solubilization process. The ratio of halo zone diameter to colony diameter of 139SI on NBRIP is $1.6 \pm 0.03$. Some of PGPR are also able to produce siderophores in order to make iron more biologically available. The inoculation of 139SI strain resulting in color changes of CAS reagent from blue to orange, a positive result for siderophores production. The ability of strain 139SI to fix the atmospheric nitrogen was qualitatively evaluated by the growth of the strain on NFb medium. Result from the experiment revealed that the strain 139SI involved in the biological nitrogen fixation process as evidenced by the formation of a veil-like pellicle near the surface of the semi-solid N-free media.

\subsection{Effects of strain 139SI inoculation on plant growth}

The effects of strain 139SI inoculation on plant growth performance were also evaluated. In the presence of strain 139SI inoculation, the vegetative growth of oil palm seedling was higher compared to uninoculated plants. Fig. 1 summarizes the incremental trend for height and diameter of oil palm seedling stem inoculated with strain 139SI. The inoculation of strain 139SI on the seedling clearly gives significant effects on height increment as early as one week after inoculation. The height of stem in inoculated group recorded markedly increases by $55.4 \%$ higher than control at the end of the experiment. Plant growth promoting effects of strain 139SI on the seedling also can be seen on the stem diameter size. After 3 weeks, seedling inoculated with strain 139SI produced stem $33.3 \%$ larger than those in the control group. The differences in stem height and diameter between inoculated and uninoculated are statistically significant. As expected, the significant increment on the height and diameter of stem give direct effects on dry weight reading. As shown in Table 2, the stem and root were $66.7 \%$ and $42.9 \%$ heavier than the control. Observation on the characteristics of the root was found that the seedling in inoculated and non-inoculated groups had one primary root and smaller lateral root branching horizontally from the primary root (Table 3 ). The length of the primary root in each group was measured weekly and it was found that the strain 139SI-inoculated seedling produced significantly longer primary root with comparison to the non-inoculated ones. The positive effects of strain 139SI inoculation on stimulating root elongation can be seen as early as first week after inoculation. The other important characteristic that has been observed was strain 139SI-inoculated seedling also 


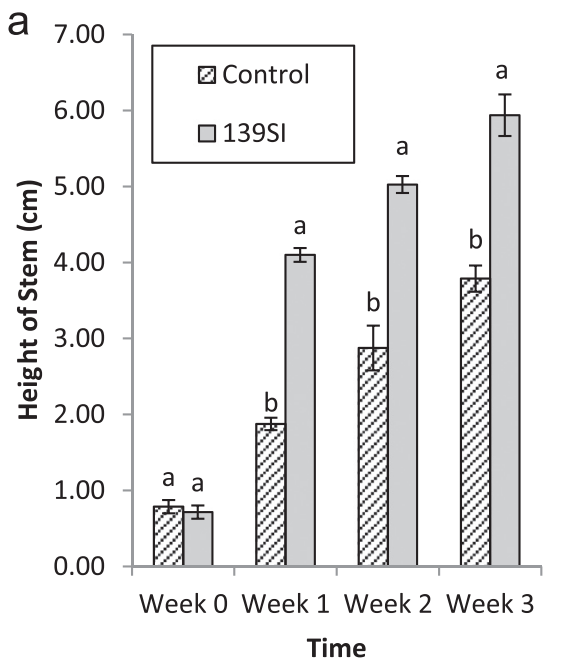

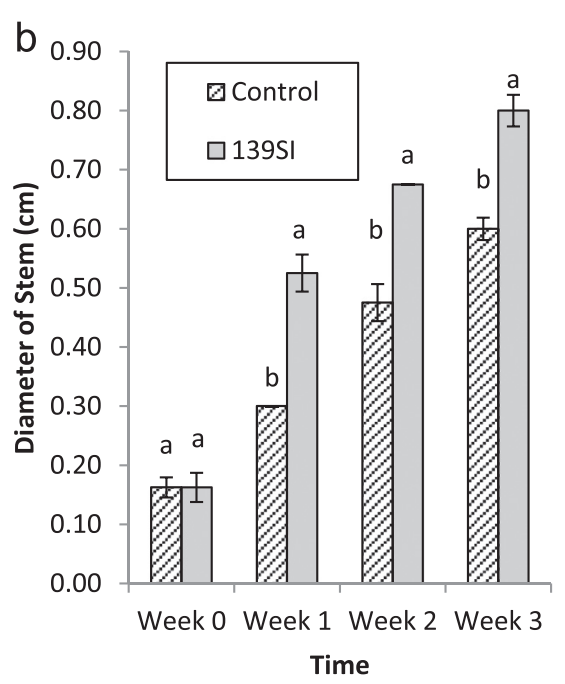

Fig. 1. Effect of strain 139SI inoculation on the (a) height and (b) diameter of stem of oil palm seedling. Data are the mean of ten samples. Vertical bars represent standard deviations. Different letters indicate significant differences between treatments according to $t$ - test $(\mathrm{p}<0.05)$. produced an increased number of lateral roots compared to the control. The average number of the lateral root increase with time. Similar as what was being observed on the elongation of the primary root, the number of lateral root was also significantly higher as early as first week after inoculation.

\subsection{Root colonization}

Colonization of strain 139SI on plant root was evidenced by SEM result as exhibited in Fig. 2. The SEM examination of the surface of plant root has detected the presence of 139SI bacterial cells on plant root samples taken on 1st, 2nd and 3rd week after inoculation. The SEM observation on plant root samples also revealed that the strain attached to the plant root surface by forming biofilm. The strain 139SI population densities in the rhizosphere soil, root surface and in the internal root tissues are shown in the Fig. 3.

The data obtained from the experiment clearly shows that the strain 139SI enables to colonize not only the surface of the plant root, but it can also penetrate and lives in the plant tissue. Significant differences were found between the CFU number of the strain in rhizosphere soil, root surface and in the internal root tissues. Same pattern of strain 139SI population distribution in these three different parts was observed from first week to third week after inoculation. Overall, the strain 139SI population densities were highest in the rhizosphere, followed on the root surface and small population was found in the internal root tissues. The results from this experiment also show that the strain 139SI population decrease over the time. A week after inoculation, strain 139SI population in rhizosphere soil was found at $7.51 \mathrm{log}$ $\mathrm{CFU} \mathrm{g}{ }^{-1}$ fresh weight. The strain population significantly decreases to 6.87 and $6.18 \log$ CFU g ${ }^{-1}$ fresh weights on the 2nd and 3rd week after inoculation respectively. Meanwhile, the strain 139SI population on root surface was $5.23 \log \mathrm{CFU} \mathrm{g}{ }^{-1}$ fresh weights on 1st week before it was slightly decreased to $5.07 \log \mathrm{CFU} \mathrm{g}{ }^{-1}$ fresh weights on 2 nd week and continues to significantly decrease to $4.06 \log$ CFU $g^{-1}$ fresh weights on 3rd week after inoculation. Colonization of the internal root tissues by strain 139SI was also detected. Strain 139SI populations in the root interior were recorded at $2.84 \log \mathrm{CFU} \mathrm{g}{ }^{-1}$ fresh weight on 1 st week after inoculation. The population then decreases slightly to 2.53 and $2.3653 \log \mathrm{CFU} \mathrm{g}{ }^{-1}$ fresh weight at 2 and 3 weeks after inoculation respectively.

\subsection{Interaction between bacterial population in rhizosphere and plant growth}

In this study, the population of strain 139SI in rhizosphere was found to be positively correlated with plant growth (Table 4). Significant linear correlations were found when an increase in stem height and diameter were analyzed against strain 139SI population size in the rhizosphere. A significant positive correlation also was observed between root length and amount of lateral root against the population size of strain 139SI all parts of the rhizosphere. Similarly, significant correlation also was observed between plant biomass against population size in soil rhizosphere, on the root surface and in endosphere.

\section{Discussions}

B. salmalaya strain 139 SI used in this study exhibited several desirable features for plant growth-promotion. One of the important plant growth-promotion traits presented by the strain 139SI, that may directly enhance the plant growth is the production of IAA. IAA is the most important auxins produced by PGPR. It acts as phytostimulation as it can directly benefit the plant root system by stimulating root development and increase the number of adventitious roots (Walia et al., 2014). Obviously, the same result was recorded in our study as root development indication such as root dry weight, length of the main root and number of lateral root showed significant increase in plant inoculated with strain 139SI compare to uninoculated group. Increase in root system will enable the plant to exploit larger soil volume, thus the plant can obtain larger amounts of nutrients. This also will benefit the bacteria that inhibit in the rhizosphere with high levels of root exudates (Ribeiro and Cardoso, 2012). We also found that the ability of strain 139SI to produce IAA is not depending on the availability of precursors

Table 2

Shoot and root dry matter of oil palm seedling inoculated with strain 139 SI.

\begin{tabular}{|c|c|c|c|c|c|c|}
\hline \multirow[t]{2}{*}{ Group } & \multirow[b]{2}{*}{ Week 1} & \multicolumn{3}{|c|}{ Shoot dry weight (g) } & \multicolumn{2}{|c|}{ Root dry weight (g) } \\
\hline & & Week 2 & Week 3 & Week 1 & Week 2 & Week 3 \\
\hline Control & $0.12 \pm 0.01 \mathrm{a}$ & $0.19 \pm 0.03 b$ & $0.21 \pm 0.03 b$ & $0.05 \pm 0.01 \mathrm{a}$ & $0.06 \pm 0.01 \mathrm{a}$ & $0.07 \pm 0.01 b$ \\
\hline 139SI & $0.14 \pm 0.02 \mathrm{a}$ & $0.25 \pm 0.02 \mathrm{a}$ & $0.35 \pm 0.02 \mathrm{a}$ & $0.05 \pm 0.01 \mathrm{a}$ & $0.08 \pm 0.02 \mathrm{a}$ & $0.10 \pm 0.01 a$ \\
\hline
\end{tabular}

The individual values are depicted as mean \pm standard deviation $(\mathrm{n}=10$ ). Different letters indicate significant differences between treatments according to $t$ - test $(\mathrm{p}<0.05)$. 
Table 3

Length of primary root and no. of lateral root of oil palm seedling inoculated with strain 139SI

\begin{tabular}{|c|c|c|c|c|c|c|c|c|}
\hline \multirow[t]{2}{*}{ Group } & \multicolumn{4}{|c|}{ Length of primary root $(\mathrm{cm})$} & \multicolumn{4}{|c|}{ No of lateral root (n) } \\
\hline & Week 0 & Week 1 & Week 2 & Week 3 & Week 0 & Week 1 & Week 2 & Week 3 \\
\hline Control & $5.1 \pm 0.70 a$ & $7.8 \pm 0.90 b$ & $11.1 \pm 2.30 \mathrm{~b}$ & $15.4 \pm 0.50 b$ & $2.3 \pm 1.00 \mathrm{a}$ & $13.3 \pm 1.40 \mathrm{~b}$ & $39.5 \pm 8.30 \mathrm{~b}$ & $62.5 \pm 5.90 b$ \\
\hline 139SI & $5.4 \pm 0.80 \mathrm{a}$ & $11.9 \pm 0.60 \mathrm{a}$ & $16.1 \pm 1.10 \mathrm{a}$ & $20.4 \pm 1.00 \mathrm{a}$ & $2.4 \pm 0.90 \mathrm{a}$ & $34.6 \pm 2.70 \mathrm{a}$ & $67.3 \pm 4.70 \mathrm{a}$ & $83.1 \pm 3.10 \mathrm{a}$ \\
\hline
\end{tabular}

The individual values are depicted as mean \pm standard deviation $(\mathrm{n}=10)$. Different letters indicate significant differences between treatments according to $\mathrm{t}-$ test $(\mathrm{p}<0.05)$.

for IAA synthesis, which is tryptophan. Although tryptophan is the most important precursor for IAA synthesis, certain PGPR are able to produce the hormone through several tryptophan-independent pathways as explained by Spaepen et al. (2009), and this would explain the production of IAA by strain 139SI in the absence of tryptophan. This, of course, is advantageous to the plant as tryptophan is not ubiquitous in the soil.

The other beneficial plant growth promoting feature of strain 139SI that can be observed was its potential to make soil more fertile by increasing the availability of nitrogen, phosphate and iron elements to the plant. Nitrogen, phosphorus, and iron are among the most crucial plant nutrient required for plant growth. Despite these elements are abundantly available in nature, they mostly exist in an unusable form to the plant (predominantly present in the form of $\mathrm{N}_{2}$, phosphate, and Fe (III) oxide) (Richardson et al., 2009; Guerinot and Yi, 1994). The atmospheric nitrogen can be converted into plant usable form by biological nitrogen fixation (BNF). Certain microbes also are able to transform insoluble phosphate in the soil into usable forms for plant utilization through processes of acidification, exchange reactions, chelation and production of organic acids (Sharma et al., 2013; Rodríguez et al., 2004). Results from our study demonstrated that a nitrogen-fixing and

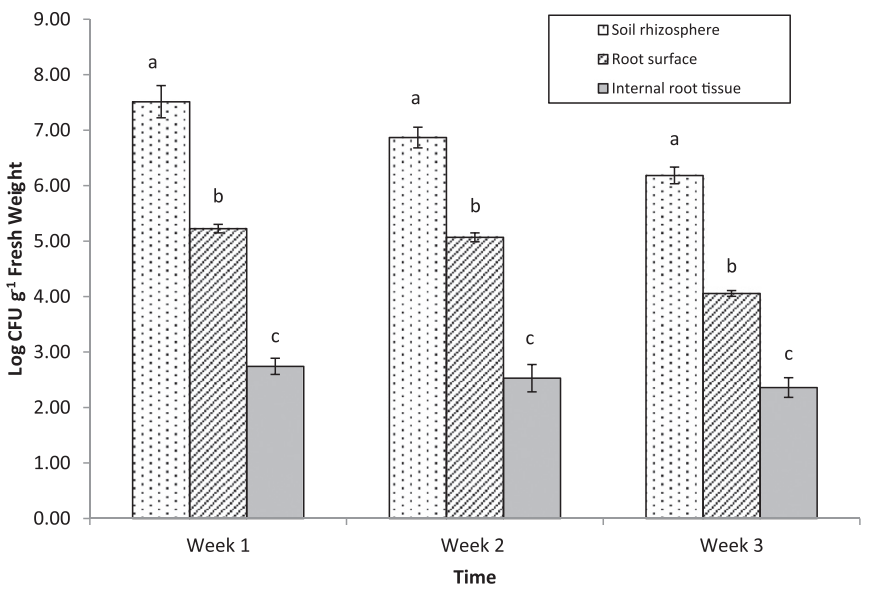

Fig. 3. Strain 139SI population densities in the soil rhizosphere, root surface and in the internal root tissues. Data are the mean of 30 samples. Vertical bars represent standard deviations. Different letters indicate significant differences between treatments according to Tukey test $(\mathrm{p}<0.05)$.
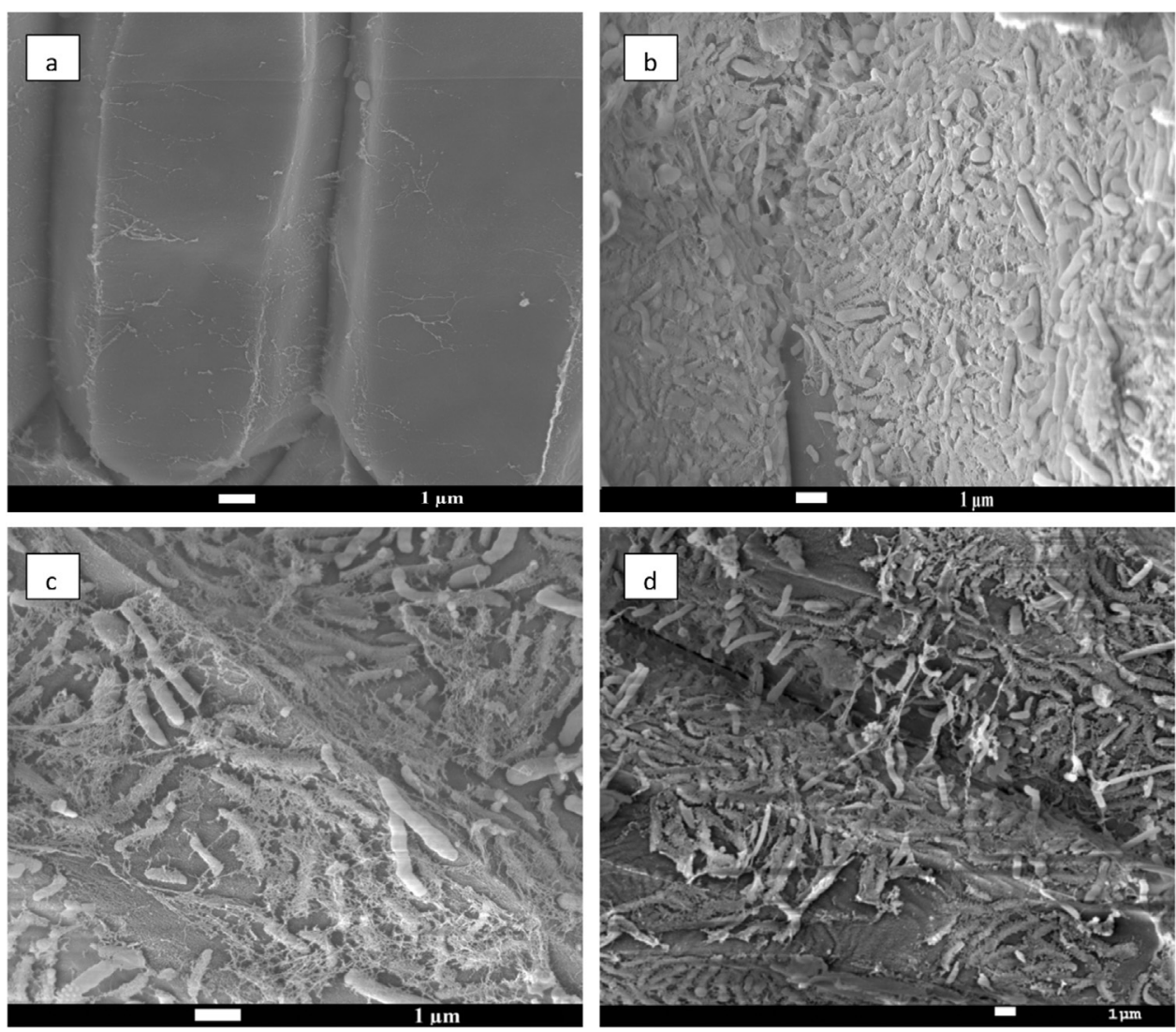

Fig. 2. Scanning electron microscopy images of primary root colonized with strain 139 SI. (a) is image of uninoculated group, (b) is SEM image of root 1st week after inoculation, (c) is SEM image of root 2nd week after inoculation and (d) is SEM image of root 3rd week after inoculation $(\mathrm{n}=3)$. Note the colonization and biofilm formation by strain 139SI on root surface (b, c, and d). 
Table 4

Pearson's correlation coefficients for the plant growth and strain 139SI population in rhizosphere.

\begin{tabular}{cccccc}
\hline & $\begin{array}{l}\text { Stem } \\
\text { height }\end{array}$ & $\begin{array}{l}\text { Stem } \\
\text { diameter }\end{array}$ & $\begin{array}{l}\text { Root } \\
\text { length }\end{array}$ & $\begin{array}{l}\text { No. of } \\
\text { lateral } \\
\text { root }\end{array}$ & $\begin{array}{l}\text { Plant } \\
\text { biomass }\end{array}$ \\
\hline $\begin{array}{c}\text { Population size in } \\
\text { soil rhizosphere }\end{array}$ & $0.679^{*}$ & $0.739^{*}$ & $0.900^{*}$ & $0.886^{*}$ & $0.568^{*}$ \\
$\begin{array}{c}\text { Population size on } \\
\text { root surface }\end{array}$ & $0.689^{*}$ & $0.729^{*}$ & $0.844^{*}$ & $0.680^{*}$ & $0.751^{*}$ \\
$\begin{array}{c}\text { Population size in } \\
\text { endosphere }\end{array}$ & $0.724^{*}$ & $0.720^{*}$ & $0.851^{*}$ & $0.605^{*}$ & $0.720^{*}$ \\
\hline
\end{tabular}

Notes:

* Significant at levels of $\mathrm{p}<0.05 . \mathrm{n}=30$

phosphate-solubilizing bacterium of strain 139SI enhances the growth of oil palm seedling. Similarly, numerous previous researchers have reported that the inoculation of phosphate solubilizing and nitrogenfixing bacteria have contributed to the growth promotion of many varieties of plant (Ahemad and Kibret, 2014).

As mentioned earlier, we also found that strain 139SI produce siderophores. Siderophores produced by strain 139SI may directly promote oil palm seedling growth by increasing the availability of iron in the soil surrounding root. According to Hansen et al. (2006), iron deficiency will result in photosynthetic rate reduction in plant because chlorophyll synthesis is inhibited in younger leaves. This eventually will inhibit growth of plants and reduces crop yield. Sharma et al. (2003) and Nagata et al. (2013) reported that the siderophores produced by bacteria enhance chlorophyll synthesis and increase chlorophyll a and chlorophyll b content in the leaves. Besides that, siderophores producing bacteria can act as a good biological control of plant diseases since efficient utilization of siderophores by these bacteria restricts the growth of the pathogenic microbes in the rhizosphere due to iron starvation (Raaijmakers et al., 1995). The potential of PGPR to promote not only plant growth, but also protects plants from pathogens has been discovered by Kloepper et al. (1980) and since then, a lot of siderophores producing bacteria have been reported effective against plant pathogen such as Fusarium (Yu et al., 2011), Colletotrichum orbicularein (Park et al., 2001), Pythium spp (Matthijs et al., 2007) and many others.

In the present study, we have also analyzed the ability of strain 139SI to colonize the rhizosphere and how the amount of 139SI population presence in the rhizosphere affected plant growth. We found that there was a significant linear correlation between the amount of strain 139SI population presence in the rhizosphere and growth of oil palm seedling. This result clearly shows the influence of strain 139SI in promoting oil palm seedling growth. The ability of PGPR to colonize the plant root is very important since a close contact of the bacteria with the plant root is needed in order for the plant to get benefit from the microbial products (Bashan, 2008). Thus, the larger population of strain 139SI in rhizosphere could provide more growth regulators and nutrient for plant. The largest population of 139SI was discovered in soil followed on the root surface and smallest population of 139SI was found in the internal root tissue. The population densities of strain 139SI in different part of rhizosphere indicate the movement of the strain in this niche. Most of strain 139SI population was found in the soil since the inoculation procedure was done by mixing the strain inoculum into the soil. Then the strain 139SI moves from rhizosphere soil to colonize plant root and finally enter the internal root tissue. The larger population of strain 139SI presence on plant root compared to the internal root tissue is similar to the phenomenon previously observed by Compant et al. (2005).

A key feature of efficient root colonization is attachment of bacteria to the plant root. Among factor that might be involved in plant rootbacterial attachments are plant lectins, $\mathrm{a} \mathrm{Ca}^{2+}$-binding bacterial protein called rhicadhesin and biofilm (Smit et al., 1991; Rudiger and Gabius, 2001; Rodriguez-Navrro et al., 2007). The results of the present study found that strain 139SI attachment to the plant root occur in the form of biofilm. The ability of this strain to form biofilm is in line with our previous results (Ismail and Dadrasnia, 2015). Biofilm associated with the plant roots have been found to be beneficial for plant growth as deeply discussed by Seneviratne et al. (2011) and Bogino et al. (2013). According to Rodriguez-Navrro et al. (2007), sufficient moisture and nutrients provided by the plant in the rhizosphere create an environment that fulfills the requisites for biofilm formation. Biofilm is one of the life strategies for bacteria in natural environments. By adhering to plant roots, the bacteria will be able to exploit various compounds in root exudates such as sugar, amino acid, organic acid and vitamin for their survival (Dakora and Phillips, 2002). This would explain the ability of the strain to maintain its high population in rhizosphere even after 3 weeks of inoculation.

\section{Conclusion}

In conclusion, our results suggest that the novel strain of B. salmalaya strain 139SI has promising features as plant growth promoting rhizobacteria. The strain was positive for indole acetic acid (IAA), nitrogen fixation, phosphate solubilization, and siderophores production, thus, indicates that the strain promotes palm growth via phytostimulation and increase the availability of nutrients to the plants. Also reported here is that the strain 139SI forms biofilms on plant root and behaves as an endophytic bacterium. Inoculation of the strain at the early stage of the growth enhances growth performance of the seedling, thus, could increase survival rates once transplanted to the field.

\section{Acknowledgement}

This research works were supported by the University of Malaya Postgraduate Research Grant (PG100-2015A) and Frontier Science (AFR) Research Cluster, University Malaya Research Grant (RP023C14AFR). The authors also would like to thank to Malaysian Palm Oil Board (MPOB) Kluang Research Station for providing the oil palm seeds.

\section{References}

Ahemad, M., Kibret, M., 2014. Mechanisms and applications of plant growth promoting rhizobacteria: current perspective. J King Saud Univ - Sci. 26, 1-20.

Azlin, C.O., Amir, H.G., Chan, L.K., Zamzuri, I., 2007. Effect of plant growth promoting rhizobacteria on root formation and growth of tissue cultured oil palm (Elaeis guineensis Jacq.). Biotechnology 6, 549-554.

Baldani, J.I., Reis, V.M., Videira, S.S., Boddey, L.H., Baldani, V.L.D., 2014. The art of isolating nitrogen-fixing bacteria from non-leguminous plants using $\mathrm{N}$-free semi-solid media: a practical guide for microbiologists. Plant Soil 384, 413-431.

Bashan, Y., 2008. Inoculants of plant growth promoting bacteria for use in agriculture. Biotechnol. Adv. 16, 729-770.

Basri, M. W., Maizura, I., SitiNorAkmar, A., and Norman, K., 2003. Oil palm: Handbook of Industrial Crops. In: Chopra, V. L. and Peter, K. V. (Eds.). The Haworth Press, New York. Oil palm: Handbook of Indus trial Crops (in press).

Bogino, P.C., Oliva Mde, L., Sorroche, F.G., Giordano, W., 2013. The role of bacterial biofilms and surface components in plant-bacterial associations. Int. J. Mol. Sci. 14 $15838-15859$.

Bremner, J.M., Mulvaney, C.S., 1982. Nitrogen-total. In: Page, A.L., Miller, R.H., Keeney, D.R. (Eds.), Methods of Soil Analysis, Part 2: Chemical and Microbiological Properties, 2nd edn. American Society of Agronomy, Inc, Madison, pp. 595-622.

Chanway, C.P., Shishido, M., Nairn, J., Jungwirth, S., Markham, J., Xiao, G., Holl, F.B., 2000. Endophytic colonization and field responses of hybrid spruce seedlings after inoculation with plant growth-promoting rhizobacteria. For. Ecol. Man. 133, 81-88.

Compant, S., Reiter, B., Sessitsch, A., Nowak, J., Clément, C., Barka, E.A., 2005. Endophytic colonization of Vitis vinifera L. by a plant growth-promoting bacterium, Burkholderia sp. strain PsJN. Appl. Environ. Microbiol. 71, 1685-1693.

Dakora, F.D., Phillips, D.A., 2002. Root exudates as mediators of mineral acquisition in low-nutrient environments. Plant Soil 245, 35-47.

Gordon, S.A., Weber, R.P., 1951. Colorimetric estimation of indoleacetic acid. Plant Physiol. 26, 192-195.

Green, M., Lima, W.A.A., de Figuereido, A.F., Atroch, A.L., Lopes, R., da Cunha, R.N.V., Teixeira, P.C., 2013. Heat-treatments and germination of oil palm seeds. J. Seed Sci. 35, 296-301. 
Guerinot, M.L., Yi, Y., 1994. Iron: nutritious, noxious, and not readily available. Plant Physiol. 104, 815-820.

Hansen, N.C., Hopkins, B.G., Ellsworth, J.W., Jolley, V.D., 2006. Iron nutrition in field crops. In: Barton, L.L., Abadia, J. (Eds.), Iron Nutrition in Plants and Rhizospheric Microorganisms. Springer, Dordrecht, Netherlands, pp. 23-59.

Ismail, S., Dadrasnia, A., 2015. Biotechnological potential of Bacillus salmalaya 139SI: a novel strain for remediating water polluted with crude oil waste. PLoS One 10, 1-13.

Jones, J.B., 2001. Laboratory Guide for Conducting Soil Tests and Plant Analysis. CRC Press, Boca Raton, FL, pp. 27-160.

Kloepper, J.W., Leong, J., Teinteze, M., Schroth, M.N., 1980. Enhancing plant growth by siderophoress produced by plant growth promoting rhizobacteria. Nature 286, 885-886.

Malaysian Palm Oil Board (MPOB), 2017. Overview of the Malaysian Oil Palm Industry 2016. Available at: 〈http://bepi.mpob.gov.my/images/overview/Overview_of Industry_2016.pdf> (Accessed 11th September 2017).

Matthijs, S., Tehrani, K.A., Laus, G., Jackson, R.W., Cooper, R.M., Cornelis, P., 2007. Thioquinolobactin, a Pseudomonas siderophore with antifungal and anti-Pythium activity. Environ. Microbiol. 9, 425-434.

Nagata, T., Oobo, T., Aozasa, O., 2013. Eficacy of a bacterial siderophores, pyoverdine, to supply iron to Solanum lycopersicum plants. J. Biosci. Bioeng. 115, 686-690.

Nautiyal, V., 1999. An efficient microbiological growth medium for screening phosphate solubilizing microorganisms. Microbiol. Lett. 170, 265-270.

Pandey, A., Palni, L.M.S., Bag, N., 2000. Biological hardening of tissue culture raised tea plants. Biotechnol. Lett. 22, 1087-1091.

Park, K., S, Ahn, I.P., Kim, H., 2001. Systemic resistance and expression of the pathogenesis-related genes mediated by the plant growth-promoting rhizobacterium Bacillus amyloliquefaciens EXTN-1 against anthracnose disease in cucumber. Mycobiology 29, 48-53.

Raaijmakers, J.M., Vandersluis, I., Koster, M., Bakker, P.A.H.M., Weisbeek, P.J., Schippers, B., 1995. Utilization of heterologous siderophoress and rhizosphere competence of fluorescent Pseudomonas spp. Can. J. Microbiol. 41, 126-135.

Ribeiro, C.M., Cardoso, E.J.B.N., 2012. Isolation, selection and characterization of rootassociated growth promoting bacteria in Brazil Pine (Araucaria angustifolia). Microbiol. Res. 167, 69-78.

Richardson, A.E., Barea, J.M., Mcneill, A.M., Prigent-Combaret, C., 2009. Acquisition of phosphorus and nitrogen in the rhizosphere and plant growth promotion by microorganisms. Plant Soil 321, 305-339.

Rodríguez, H., Gonzalez, T., Goire, I., Bashan, Y., 2004. Gluconic acid production and phosphate solubilization by the plant growth-promoting bacterium Azospirillum spp.
Naturwissenschaften 91, 552-555

Rodriguez-Navrro, D.N., Dardanelli, M.S., Ruiz-Sainz, J.E., 2007. Attachement of bacteria to the plant roots of higher plants. FEMS Microbiol. Lett. 272, 127-136.

Rudiger, H., Gabius, H.J., 2001. Plant lectins: occurrence, biochemistry, functions and applications. Glycoconj. J. 18, 589-613.

Schwyn, R., Neilands, J.B., 1987. Universal chemical assay for detection and determination of siderophoress. Anal. Biochem. 160, 47-56.

Seneviratne, G., Weerasekara, M.L.M.A.W., Seneviratne, K.A.C.N., Zavahir, J.S., Kecskes, M.L., Kennedy, I.R., 2011. Importance of biofilm formation in plant growth promoting rhizobacterial action. Microbiol. Monogr. 18, 81-95.

Sharma, A., Johri, B.N., Sharma, A.K., Glick, B.R., 2003. Plant growth-promoting bacterium Pseudomonas sp. strain GRP3 influences iron acquisition in mung bean (Vigna radiate L. Wilzeck). Soil Biol. Biochem. 35, 887-894.

Sharma, S.B., Sayyed, R.Z., Trivedi, M.H., Gobi, T.A., 2013. Phosphate solubilizing microbes: sustainable approach for managing phosphorus deficiency in agricultural soils. Springerplus. 2, 587.

Smit, G., Tubbing, D., Kjine, J., Lugtenberg, B., 1991. Role of Ca21 in the activity of rhicadhesin from Rhizobium leguminosarum biovarviciae which mediates the first step in attachment of Rhizobiaceae cells to plant root hair tips. Arch. Microbiol. 55, 278-283.

Sogeke, A.K., 1998. Stages in the vegetative propagation of oil palm, (Elaeis guineensis) Jacq. through tissue culture. J. Oil Palm Res. 10, 1-9.

Spaepen, S., Vanderleyde, J., Okon, Y., 2009. Plant growth-promoting actions of rhizobacteria. In: Van Loon, L.C. (Ed.), Advances in Botanical Research 51. Academic Press, Burlington, pp. 283-320.

Sturz, A.V., Nowak, J., 2000. Endophytic communities of rhizobacteria and the strategies required to create yield enhancing associations with crops. Appl. Soil Ecol. 15, 183-190.

Thomas, G.W., 1996. Soil pH and soil acidity. In: Sparks, D.L. (Ed.), Methods of Soil Analysis, Part 3, Chemical Methods. Soil Science Society of America, Madison, pp. 475-490.

Wahid, M.B., Nor, S., Abdullah, A., Henson, I.E., 2005. Oil Palm - achievements and Potential. Plant Prod. Sci. 8, 1-13.

Walia, A., Mehta, P., Chauhan, A., Shirkot, C.K., 2014. Effect of Bacillus subtilis strain CKT1 as inoculum on growth of tomato seedlings under net house conditions. Biol. Sci. 84, 145-155.

Yu, X., Ai, M.C.X., Xin, L., Zhou, G.F., 2011. The siderophores-producing bacterium, Bacillus subtilis CAS15, has a biocontrol effect on Fusarium wilt and promotes the growth of pepper. Eur. J. Soil Biol. 47, 138-145. 